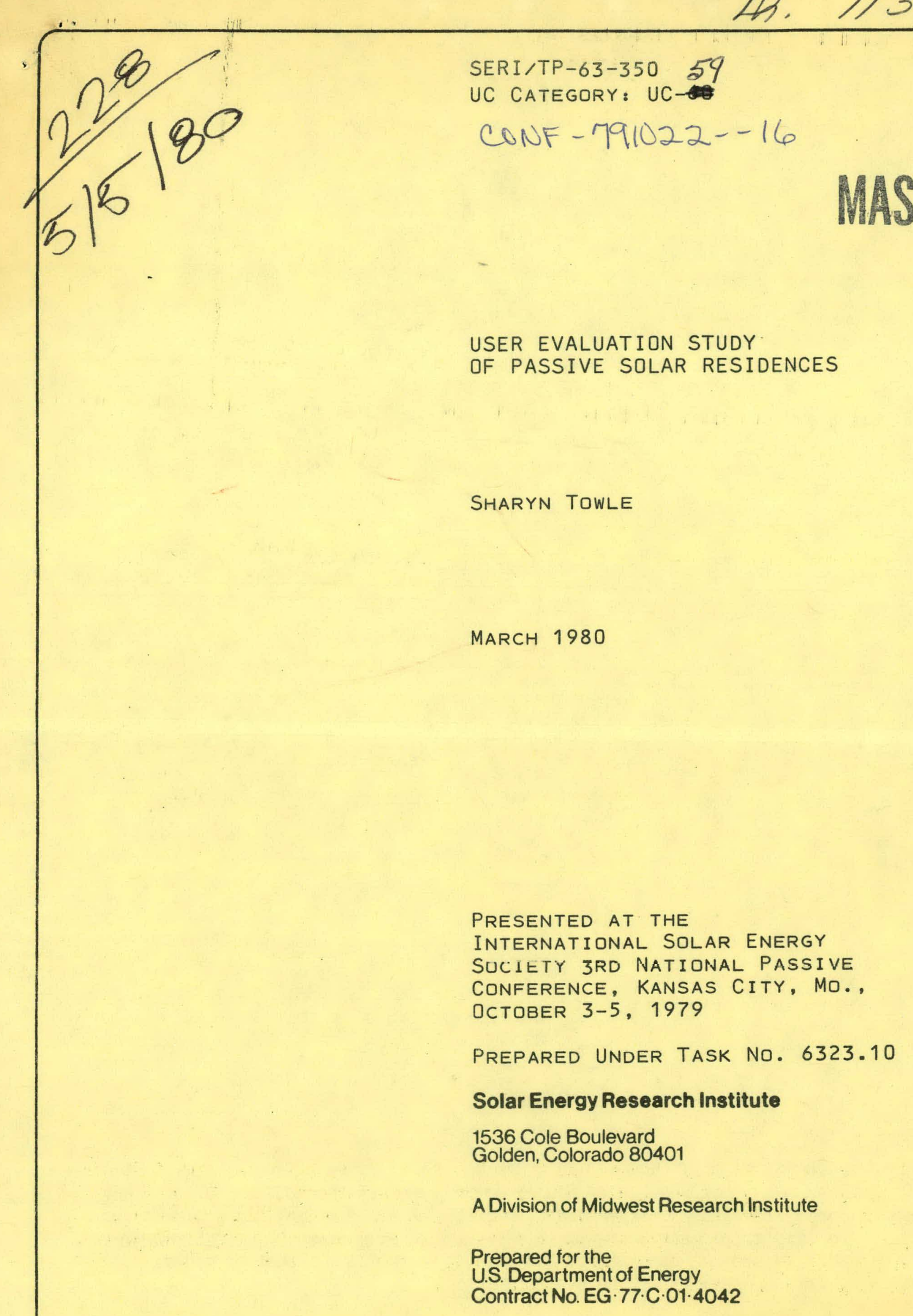




\section{DISCLAIMER}

This report was prepared as an account of work sponsored by an agency of the United States Government. Neither the United States Government nor any agency Thereof, nor any of their employees, makes any warranty, express or implied, or assumes any legal liability or responsibility for the accuracy, completeness, or usefulness of any information, apparatus, product, or process disclosed, or represents that its use would not infringe privately owned rights. Reference herein to any specific commercial product, process, or service by trade name, trademark, manufacturer, or otherwise does not necessarily constitute or imply its endorsement, recommendation, or favoring by the United States Government or any agency thereof. The views and opinions of authors expressed herein do not necessarily state or reflect those of the United States Government or any agency thereof. 


\section{DISCLAIMER}

Portions of this document may be illegible in electronic image products. Images are produced from the best available original document. 


\section{NOTIC.R}

This report was prepared as an account of work sponsored by an agency of the United States Government. Neither the United States nor any agency thereof, nor any of their employees, makes any warranty, expressed or implied, or assumes any legal liability or responsibility for any third party's use or the results of such use of any information, apparatus, product, or process disclosed in this report, or represents that its use by such third party would not infringe privately owned rights. 


\title{
USER EVALUATION STUDY OP PASSIVE SOLAR RESIDENCES
}

\author{
Sharyn Towle \\ Solar Energy Research Institute \\ 1536 Cole Boulevard \\ Golden, Colorado 80401
}

\begin{abstract}
Speculation exists regarding the readiness of various passive techniques for commercialization and the market potential for residential applications. This paper discusses the preliminary findings of a market assessment study designed to document user experiences with passive solar energy. Owners and builders of passive solar homes were interviewed and asked to comment on personal experiences with their homes.
\end{abstract}

\section{NTTRODUCTION}

Market acceptability of passive solar residences was the subject of an exploratory SERI study designed to document user experiences with their passive solar homes. A major objective was to begin the collection of information that would be useful to architects, builders, and developers in passive solar residential design and planning.

Focused, unstructured, personal interviews were conducted during the spring of 1979 with residents of 21 passive solar houses that were built speculatively or were judged to be adaptable to the mass housing market. The length of the interview and number and type of questions were individualized. This method was chosen to colleet extensive information from a limited number of respondents. In addition, it provided flexibility by allowing the respondent to introduce topics and focus on issues that he or she felt were important.

The homes selected for the study were located in Oregon, Mississippi, Pennsylvania, Ohio, Wisconsin, and Connecticut and represented $a$ wide range of passive solar system types. Market value varied from $\$ 25,000$ to over $\$ 100,000$. Occupants were asked to comment on their purchase decision process and give a post occupancy evaluation of their home in terms of aesthetics, thermal comfort, lifestyle changes, financial concerns, system performance, and overall satisfaction. In most cases, the architect or builder of the home was interviewed regarding their experience with the design, construction, and marketability of passive solar homes for the mass housing market. Any changes they would make in these areas as a result of their experience were also noted.

Because this study was exploratory, results are preliminary and should not be generalized. Based on these findings, an extensive, quantitative study of passive solar users will be conducted during FY80.

\section{BACKGROUND}

Early in the study, the following parameters were set: to locate homes that would appeal to the average homebuyer and to talk with persons who were not necessarily committed to the development of passive solar energy. In addition, a decision was made to identify homes that had received little or no prior publicity, did not differ radically from neighboring homes, and were in geographic locations considered marginal for solar utilization. Emphasis was on the speculative home in an effort to avoid the emotional involvement and biases concomitant with custom passive solar homes.

Letters requesting information on passive solar speculative homes were sent to state energy offices, energy extension services, local solar energy associations, and to architects, builders, and developers involved in passive solar construction. Response was good, but very few sources were able to identify speculative homes; it appeared that passive solar design was just breaking into the speculative market. Many of the houses identified were under construction. As a result, about half of the persons interviewed had participated in the design process, but, for the most part, their involvement was minimal and did not include the passive solar system.

A total of 21 persons were interviewed in their homes. Passive solar system types included nine direct gain systems with varying amounts of storage, six isolated gain systems (solariums), one indirect gain system (concrete block wall), one underground home with a direct gain system, and

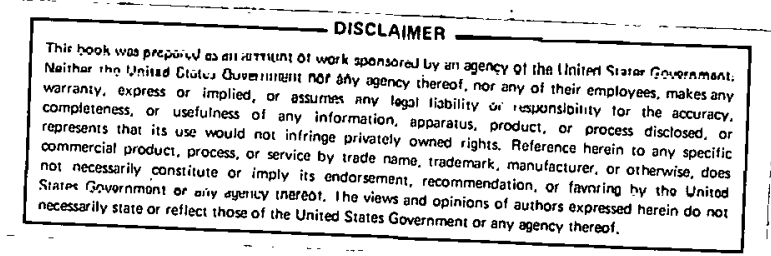


four earth-bermed homes with some direct gain. With one or two exceptions, the residents were very positive about their homes.

\section{METHODOLOGY}

Interviews with the occupants were informally organized around the following topical areas.

\subsection{Purchase Decision Process}

- Relative importance of factors that influenced the purchase decision (location, price, quality of construction, architectural style, floor plan, amenities, passive solar system, energy conscious materials, etc.)

- Buyer knowledge of passive solar energy principles prior to purchase

- Financial concerns unique to buying a passive solar home

\subsection{Post Oceupancy Bvaluation of the Home}

- Aesthetics

- occupant evaluation of the interior and exterior design

- integration of the passive solar design into the neighborhood

- comments from neighbors and friends

- Thermal Comfort

- need for and type of backup system

- temperature swing allowed by occupants

- heat distribution from the passive solar system

- Thermal Performance

- builder/designer estimates

- occupant expectations

- actual performance to date and how it is being determined

- type of monitoring system, if any

- Lifestyle Changes

- psychological effect of increased interior sunlight in direct gain systems or lack of view or daylight in mass wall systerns, underground homes, and bermed homes

- any social behavioral changes within the family that occurred as a result of living in the home, e.g., sensitivity toward energy usage, heightened environmental concerns, recycling, gardening, transportation, etc.

- clothing requirements

- need for occupant intervention in the operation of the system, e.g., movable insulation, dampers, vents, shading devices, etc.

- any personal inconveniences to family members which they attributed to the passive solar system
- positive and negative factors associated with passive solar homes

- Interior Treatments

- suggestions, if any, offered by the designer or builder regarding appropriate interior design treatments for a passive solar home

- any problems with the selection of window or noor coverings, fabrics, etc, due to the passive solar design

- if an interior designer was employed, was he or she knowledgeable about the limitations and requirements of passive solar design

- what type of movable insulation, if any, was being used and was it purchased or constructed by the occupant

- User Ealuation of the Passive Solar System

- livability of the home

- any problems and how they were solved

- changes they would make in the design, if possible

- would they do it again

\section{PORCHASB DECISTON PROCESS}

During the interviews, location, price, and design were mentioned by the passive solar homeowners as the most important factors in their purchase decision. Many of them stated that skepticism about the home's passive solar system and its potential energy savings made them unwilling to invest heavily in what they considered to be an unproven technology. For most, the passive solar system was a consideration but was not eritical to the purchase decision. As one homeowner stated, "we bought our home because it fit our. family's needs and we felt comfortable with the design and floorplan, not because of the solar system." In general, persons who had participated in the design, even minimally, were more concerned with the solar system than those who bought a speculative house. Owners of custom and semi-custom homes considered the builder's knowledge of solar energy and experience in building solar homes in their decision to purchase the home. Only one of the respondents had any problem obtaining financing due to the passive solar system.

While it appears that the traditional reasons for buying a home remain the most important factors in the purchase decision process, it was obvious from the discussions that consumers are becoming increasingly aware of household energy consumption. Respondents mentioned that Prequent comparison of utility bills with friends and neighbors demonstrated realizable cost savings of passive solar homes. Builders reported that passive solar, or suntempered homes, as many prefer to call them, are experiencing a substantial increase in market appeal. Some of the designs and marketing strategies of the tract builder may be a disappointinent to passive solar purists, but it is important to note that, at this time, radical design changes and high 
initial costs are unacceptable to both the builder and the consumer. Resale value is very important to homeburyers and influences the design and cost limitations on passive solar systems for the mass housing market.

\section{POST OCCUPANCY EVALUATION}

\subsection{Aesthetics}

Because the design and floorplan were frequently mentioned as important factors in the purchase decision process, it is not surprising that respondents were generally satisfied with the interior and exterior design of their home. Many had minor changes that they would like to make in the floorplan or room sizes, but these were insignificant.

Occupants had positive comments regarding the architectural integration of the passive solar system into the home and felt that it fit well in their neighborhood Reaction to the home from friends and neighbors was also favorable. Respondents reported that it was common for visitors to leave the home with a far more positive attitude toward passive solar homes than when they entered. Visitor questions generally focused on the home's energy. savings and comfort levels. Occupants of passive solar homes seemed to enjoy their role of information disseminetors although most reported at least one unhappy incident with uninvited guests.

\subsection{Thermal Comfart}

Few of the respondents allowed the temperature to fluctuate more than a few degrees in their home. In two homes, one in Oregon and one in Coloredo, residents accepted temperature fluctations, and the passive solar system supplied close to $100 \%$ of thelr space heating needs. In these homes, wood was used as the only backup heating source for the 1978-79 heating season. The majority used conventional backup systems to keep their home at a constant temperature - usually between $68^{\circ}$ and $70^{\circ} \mathrm{F}$.

Some problems with heat distribution were cited, but in general, occupants had high praise for the thermal comfurt of llweir homes and accepted the fact that rooms on the south side were warmer than rooms on the north side of the house. Residents of the bermed homes and the underground home seemed to be the most satisfied with comfort levels. Homes oriented away from the street with berms on the street side were reported to be quiet. One family noticed that their children responded to the low noise level in the home by lowering their voices.

\subsection{Thermal Performance}

The majority of builders were able to provide prospective buyers with only vague thermal performunce predictions for their passive solar homes. Those with engineering backgrounds or consultants had performance figures, but in most cases buyers were told to expect considerable energy savings - usually 40-50\%. This obviously presents problems because few persons are willing to invest in a promise.

Most of the passive solar homeowners interviewed casually monitored their home's performance by comparing utility bills with those of their former home and bills of neighbors who lived in comparably sized houses. Most were pleased with their relatively low fuel bills, and appeared to be spreading the word about the fuel savings. Those who were experiencing better thermal performance than they had expected were the most enthusiastic about passive solar energy. Underestimating rather than overestimating the system's performance appears to be a good strategy.

Only one, the underground home, was being monitored with any type of sophisticated monitoring equipment. Calculations predicting an $80 \%$ solas efficiency were performed by the designer/builder during the design phase. Based on the data collected during the 1978-79 heating season, the home was performing better than predicted. Residents had not used the backup heating system. It should be noted that this family also appeared to be the most committed to the development of passive solar energy of any of the respondents. It is generally recognized that the occupants' lifestyle is the single most important factor in determining household energy consumption.

\subsection{Lifestyle Changes}

Respondents reported that they had experienced no major lifestyle changes as a result of living in a passive solar house. Some felt the whole question of lifestyle changes was ridiculous. One respondent stated, "complete comfort is very important to my family, and we are not willing to sacrifice one degree of heating or cooling." This was one end of the spectrum. Another respondent, whose family lived through the winter without using any fossil fuel for space heating said, "yes, there wore times when it was chilly - one night we had a family conference to discuss turning on the purnace, but we decided not to - you might say we were trying to make a statement." Most fell somewhere in between. They were aware of their position as innovators and were conscious of their image.

Some things mentioned as marginally affecting the residents' daily routines included the joys and tribulations of tending a wood stove. Some saw this as an enjoyable task while others felt that wood stoves were dirty and troublesome. Also, many persons were pleased that the design of the home permitted them a closer contact with the natural environment. Very lew were using movable insulation or were required to operate manual devices, but many mentioned that they would like to have night insulation for their windows. Lethargy, cost, and availability or a combination of the three were the main berriers to installation of night insulation.

Some problems were reported regarding glare in direct gain systems. Drawing drapes or closing blinds was the easiest method to reduce glare 
although moving to another room and even wearing sunglasses were mentioned as solutions. The sunglass wearer also had some problems with heat distribution in his home and he reported that he wore shorts and tee shirts a lot during sunny, winter days.

Aside from glare, no one mentioned any problems with too much or too little daylight. One finel attribute to passive solar living concerned health: some of the respondents mentioned that they had slept better and that their families had experienced fewer colds since moving into their home.

\subsection{Intericr Treatments}

Most of the residents of homes with direct gain passive systems had been aware of the potential problem with sun degradation of furniture, fabries, carpeting, and window coverings, but none had consulted an interior designer for advice and few had taken any precautions to guard against sun damage. Most of the respondents had lived in their homes for a short time and had not experienced any major problems.

One woman had had a pottery table and chairs made for the eating area in her solarium which she felt was the perfect solution to this potential problem. Most of the homes had an abundance of indoor plants which were growing prolifically and were being used as focal points of the interior.

Some of the homes included Mexican quarry tile and brick floors or fireplace walls and a few had some form of water storage. No one expressed any dissatisfaction with the storage medium in their home, bu't some mentioned that visitors sometimes commented on the unconventional nature of their home's interior.

\subsection{General Comments}

Passive solar homeowners interviewed unanimously endorsed the livability of their home. Any problems encountered were minor and readily solved. Problems seem ed to concentrate on fine-tuning the system, e.g., modifying dampers in the Trombe wall, installing shading on a greenhouse, reducing glare in a direct gain system and getting the bugs out of a beadwall system.

Respondents frequently mentioned that a large part of their satisfaction was related to a good working relationship with their builder. It appeared that both consumer and builder considered themselves innovators in passive solar homebuilding and had established a joint venture in proving that passive solar systems work. An interesting finding was the increased enthusiasm reported by the residents since purchasing the home. While the majority stated that they would not have paid more for a passive solar home than a conventional heated home at the time of their purchase, they would be willing to pay more for a passive system in their next home. They attributed this change to their positive experience with their present home. With only one or two exceptions, respondents stated, "we will never again live in any home that is not passive solar heated."

Most respondents felt that the worsening energy situation increased the value of their homes and very few had any qualms about their marketability and resale value.

\section{BUILDER' VIBWPONT}

Passive solar design is an excellent solution to the homebuyer's demand for energy conscious housing. Many builders feel that the discretionary market is the strongest for passive solar homes because it permits flexibility in choosing upgraded materials which work well, both aesthetically and functionally, with passive solar applications. Greenhouses or solariums are popular with this segment of the market because of the combined appeal of added living space, passive solar heating, and the space to grow house plants and vegetables yearround.

Socio-economically, the need for passive solar housing is greatest in the low-cost market. The problem for the builder is in controlling first costs. Careful planning of orientation, window placement, floor plan, and landscaping can substantially reduce household energy consumption at little or no additional cost.

According to one very successful passive solar homebuilder, builders who are interested in the technology should:

- Evaluate their submarket to determine the demand for passive solar housing;

- Begin with simple techniques such as southern orientation, with the building elongated on the east/west axis. Most of the windows should face south and be properly shaded during the summer;

- Use passive solar consultants on more complicated systems to avoid costly errors;

- Develop a personal expertise in the subject. There are several excellent reference books available and many universities and community culleges aire offering courses on passive solar energy;

- Plan initially to spend some extra time with employees and subcontractors in the principles of passive solar energy;

- Have detailed plans and a good supervisor on the job site; and

- Have an attractive model home if volume permits. An informative brochure and knowledgeable sales people make selling passive solar homes easier.

\section{CONCLUSIONS}

It appears that passive solar systems can be effectively integrated into speculatively built homes, but 
design and first costs must be considered carefully. The uncertain energy situation will increase the market appeal of passive solar homes if they are marketed as aesthetically pleasing, competitively priced, energy conscious homes. However, today's homebuyers are still very concerned with location, traditional aesthetic appeal, and resale value; and builders should not expect the passive solar system to sell the home.

To date, builders entering the passive solar home market are challenged by lack of public awareness regarding passive solar energy and lack of good documentation on performance of passive solar system types. Efforts in communications, marketing, and design tool development, in both the public and the private sector, are helping to remedy this situation by providing the information needed to stimulate the market. 